\title{
Pengaruh Pemanfaatan Media Online terhadap Minat Berwirausaha pada Mahasiswa \\ (Studi Kasus di Sekolah Tinggi Multi Media “MMTC” Yogyakarta)
}

\author{
Dhety Chusumastuti \\ Sekolah Tinggi Multi Media "MMTC Yogyakarta \\ Email: dhet001@kominfo.go.id
}

Abstract

This study aims to determine the effect of Online Media Utilization on Entrepreneurial Interest in Students at STMM Yogyakarta. The sample in this study were 94 students at STMM Yogyakarta. Data was collected by survey method by giving a list of questions or questionnaires directly to the respondents. Data analysis techniques in this study used Simple Regression analysis, and t test which was operated through the SPSS program. The results showed that the use of online media had a positive and significant influence on entrepreneurial interest in students at STMM Yogyakarta.

Keywords: Interest, Entrepreneurship, Online Media Utilization

Abstrak

Penelitian ini bertujuan untuk mengetahui pengaruh Pemanfaatan Media Online terhadap Minat Berwirausaha pada Mahasiswa di STMM Yogyakarta. Sampel dalam penelitian ini adalah mahasiswa di STMM Yogyakarta yang berjumlah 94 orang. Data dikumpulkan dengan metode survei yaitu dengan memberikan daftar pertanyaan atau kuesioner secara langsung kepada para responden. Teknik analisis data dalam penelitian ini menggunakan analisis Regresi Sederhana, dan Uji t yang dioperasikan melalui program SPSS. Hasil penelitian menunjukkan bahwa Pemanfaatan Media Online mempunyai pengaruh positif dan signifikan terhadap Minat Berwirausaha pada mahasiswa di STMM Yogyakarta.

Kata kunci: Minat, Kewirausahaan, Pemanfaatan Media Online

(C) 2020 Jurnal Riset Inspirasi Manajemen dan Kewirausahaan

\section{PENDAHULUAN}

Perkembangan kewirausahaan di Indonesia akhir-akhir ini berkembang cukup pesat. Hal tersebut ditunjukkan dengan angka rasio wirausahawan di Indonesia yang sudah mencapai $7 \%$ di tahun 2018, yang berarti meningkat pesat apabila dibandingkan dengan tahun 2017 yang hanya mencapai $3,1 \%$, bahkan pada tahun 2016 baru mencapai 1,67\%. Rasio di tahun 2017 dan 2018 tersebut sudah memenuhi standar internasional yang mensyaratkan rasio wirausahawan diatas $2 \%$. PBB menyatakan bahwa suatu Negara akan dapat membangun, apabila rasio wirausaha di negaranya di atas $2 \%$. Meskipun begitu rasio tersebut ternyata masih sangat jauh apabila dibandingkan dengan negara-negara maju, yang rata-rata sudah mempunyai rasio di atas $14 \%$. Data peningkatan rasio wirausahawan di Indonesia tersebut dikemukakan oleh Menteri Koperasi dan UKM pada waktu itu yaitu Anak Agung Gede Ngurah Puspayoga dalam wawancaranya dengan sindonews.com pada bulan Juni 2018. Data rasio wirausahawan dapat dilihat pada tabel berikut:
Tabel. 1

Data Rasio Wirausahawan diIndonesia

\begin{tabular}{cc}
\hline Tahun & Presentase \\
\hline 2016 & $1,67 \%$ \\
2017 & $3,1 \%$ \\
2018 & $7 \%$ \\
\hline
\end{tabular}

Sumber: www.ekbis.sindonewes.com, data diolah 2019

Rasio wirausaha ini adalah perbandingan antara jumlah wirausahawan dan jumlah penduduk di suatu Negara. Inilah pentingnya wirausahawan di suatu Negara, karena wirausahawan dapat menciptakan lapangan pekerjaan, sehingga akan meningkatkan kesejahteraan masyarakat, yang artinya akan meningkatkan juga pertumbuhan ekonomi di Indonesia.

Perkembangan kewirausahaan ini juga dapat ditunjukkan dengan bermunculannya usaha-usaha rintisan baru yang mulai beroperasi, istilah kerennya saat ini adalah startup. Saat ini banyak wirausahawan muda yang menghiasi panggung 
bisinis di Indonesia. Sebagai contoh Nadiem Makarim sebagai CEO Go-jek, Achmad Zaky sebagai CEO Bukalapak, Andrew Darwis salah satu pendiri KasKus, Belva Devara dan Iman Usman sebagai pendiri Ruang Guru dan masih banyak lagi wirausahawan muda yang bermunculan akhir-akhir ini yang pada saat mereka mendirikan perusahaan tersebut usianya masih sangat muda. Memperhatikan dari trend bisnis yang dibuat para wirausahawan muda tersebut, dapat kita lihat sebagian besar dari mereka mengandalkan teknologi informasi dan komunikasi. Di jaman yang serba digital seperti saat ini tentulah lebih mudah untuk melakukan pemasaran sebuah produk baik itu barang maupun jasa. Media promosi yang digunakan juga sudah tidak terbatas pada media cetak dan elektronik. Media online sudah dipandang sebagai media yang lebih efektif dan efisien dalam melakukan pemasaran.

Hal ini berarti juga harus menjadi perhatian pemerintah untuk dapat terus meningkatan jumlah wirausahawan dan memfasilitasi wirausahawan yang sudah ada. Kebijakan yang telah dilakukan antara lain adalah membuat aturan-aturan untuk dunia usaha, kebijakan perpajakan yang diusahakan untuk meringankan para pelaku usaha kecil menengah, kebijakan pemberian kredit usaha, membangun infrastruktur telekomunikasi, hingga yang saat ini yang sedang populer adalah target menciptakan 1000 startup bagi anak-anak muda yang berminat mengembangkan ide-ide usahanya.

Fenomena tersebut di atas dapat pula memotivasi para anak muda untuk memulai usahanya. Begitu pula dengan mahasiswa yang ada di Sekolah Tinggi Multi Media Yogyakarta (STMM Yogyakarta), bisa jadi sudah banyak yang mempunyai bisnis secara offline maupun online karena berbagai kemudahan di era digital saat ini. Berdasarkan data dari Sub Bagian Kemahasiswaan dan Alumni STMM Yogyakarta, lulusan STMM Yogyakarta dari tahun 2005 sampai dengan tahun 2018 berjumlah 1528 mahasiswa, dan sekitar 4\% diantaranya bekerja sebagai wirausahawan. Dilihat dari jumlahnya memang terlihat sedikit, tetapi mengingat STMM Yogyakarta bukan sekolah di bidang ekonomi dan bisnis ataupun sekolah enterpreneur, jumlah ini dapat dikatakan cukup. Hal ini juga dapat disebabkan oleh penggunaan media online yang sangat mudah diakses di jaman sekerang. Berbekal gadget di tangan saat ini siapapun sudah dapat mulai berjualan. Banyak saluran yang dapat digunakan misalnya media sosial, forum atau komunitas online, web, iklan di internet, dari yang gratis sampai yang berbayar. Pilihan tersebut biasanya akan tergantung dari kemampuan modal yang ada atau juga berdasarkan target pasarnya.

Pemanfaatan media online untuk sarana berwirausaha menjadi penting untuk mandapatkan gambaran bagaimana pemanfaatan media tersebut oleh para pengguna (mahasiswa) saat ini, sehingga dapat menjadi inputan bagi pengembangan kebijakan dalam meningkatkan kompetensi lulusan sekolah tinggi multimedia di bidang kewirausahaan. Hal ini dapat menunjang kualitas lulusan STMM Yogyakarta dan untuk mengurangi masa tunggu lulusan mendapatkan pekerjaan, karena mahasiswa yang sudah lulus langsung dapat bekerja sebagai wirausahawan. Berdasarkan beberapa hal di atas, maka peneliti tertarik untuk mengambil judul "Pengaruh Pemanfaatan Media Online terhadap Minat Berwirausaha pada Mahasiswa (Studi Kasus di Sekolah Tinggi Multi Media "MMTC" Yogyakarta)".

\section{KAJIAN LITERATUR}

Menurut Djamarah (2011), minat merupakan aktivitas atau kegiatan yang menetap dan dilakukan untuk memperhatikan dan mengenang beberapa aktivitas yang disukai baik disengaja atau tidak. Jika seseorang memiliki minat terhadap suatu aktifitas maka mereka bisa menyukai dan memperhatikan aktivitas itu dengan rasa senang. Menurut Husamah, dkk., (2016), minat ini timbul apabila seseorang tertarik akan sesuatu karena sesuai dengan kebutuhannya atau merasa bahwa sesuatu yang akan dilakukan dirasakan bermakna bagi dirinya. Namun demikian, minat tanpa adanya usaha yang baik maka sesuatu yang akan dilakukan tersebut juga sulit untuk berhasil.

Menurut Takdir, dkk., (2015), kewirausahaan adalah sikap mental atau kemampuan seseorang yang selalu berusaha untuk meningkatkan hasil dan mengejar peluang memenuhi kebutuhan dan keinginan melalui inovasi. Wirausaha adalah orang atau pelaku usaha yang memiliki kemampuan melihat dan menilai kesempatan usaha, mengumpulkan sumberdaya yang dibutuhkan guna mengambil keuntungan dan tindakan yang tepat guna dalam memastikan keberhasilan. Jadi, minat berwirausaha adalah ketertarikan, perhatian, focus, dan kesukaan sesorang dalam bidang kewirausahaan. Suryana (2013) menjelaskan kewirausahaan adalah suatu disiplin ilmu yang mempelajari tentang nilai, kemampuan, dan perilaku seseorang dalam menghadapi tantangan hidup dan cara memperoleh peluang dengan berbagai risiko yang mungkin dihadapinya.

Rusdiana (2018) mengemukakan pentingnya minat dalam berwirausaha karena dengan adanya 
wirausaha dapat memberikan sumbangan dalam meningkatkan pembangunan ekonomi. Wirausaha memberikan kontribusi terhadap lancarnya proses produksi, distribusi, dan konsumsi. Wirausaha dapat membuka lapangan kerja sehingga meningkatkan pendapatan masyarakat, wirausaha dapat meningkatkan ketahanan nasional, dan dapat mengurangi ketergantungan pada bangsa asing. Seseorang yang tertarik dengan wirausaha biasanya akan bekerja keras untuk mewujudkan keinginan dalam memenuhi kebutuhan hidupnya dan tidak takut menghadapi resiko.

Indikator dari minat berwirausaha menurut Suryana, (2013) meliputi:

1. Percaya diri

Seseorang yang percaya diri akan selalu percaya bahwa dirinya mampu melakukan sesuatu, tidak tergantung dengan orang lain, berkepribadian mantap, dan selalu optimis.

2. Berorientasi tugas dan hasil

Seseorang yang berorientasi terhadap tugas dan hasil akan selalu bekerja keras untuk mewujudkan hasil yang diinginkan, dan menganggap prestasi adalah suatu kebutuhan.

3. Pengambilan resiko

Seseorang yang berani mengambil resiko akan memberikan kontribusi yang baik dalam berwirausaha agar terbiasa dengan tantangan dan resiko yang akan terjadi terhadap segala keputusan yang diambil.

4. Kepemimpinan

Kemampuan mempimpin ini memang beda tergantung masing-masing individu. Pemimpin yang baik harus mampu memahami permasalahan organisasi, mau mendengarkan pendapat orang lain, mau menerima kritik dan saran yang membangun, dan dapat bekerjasama dengan bawahannya.

5. Keorisinilan

Seorang wirausahawan selalu berusaha menjadikan suatu produk yang akan dibuatnya orisinil yaitu tidak meniru hasil orang lain. Meskipun demikian, orisinil bukan berarti harus selalu baru, namun tetap terdapat inovasi dalam penemuannya, serta mempunyai kekhasan dalam produknya.

6. Berorientasi ke masa depan.

Seseorang yang berorientasi ke masa depan adalah orang yang selalu selangkah lebih maju, selalu mempunyai pandangan ke depan (visioner), dan selalu dapat membuat perencanaan yang strategis untuk jangka panjang.

Menurut Romli (2012), media online disebut juga media siber, media internet, dan media baru, dapat juga diartikan sebagai media yang tersaji secara online di situs web internet. Media online dapat dikatan sebagai media generasi ketiga setelah media cetak (koran, majalah, dan buku) dan media elektronik (radio, televisi, dan film/video). Secara teknis, media online adalah media berbasis telekomunikasi dan multimedia (komputer dan internet). Termasuk dalam kategori media online adalah portal, website (situs web, termasuk blog dan media sosial seperti facebook dan twitter), radio online, $\mathrm{TV}$ online, dan email. Dalam perspektif studi media atau komunikasi masa, media online menjadi objek kajian teori "media baru" yang istilahnya mengacu pada permintaan akses ke konten kapan saja, di mana saja, pada setiap perangkat digital serta umpan balik pengguna interaktif, partisipasi kreatif, dan pembentukan komunitas sekitar konten media, juga aspek generasi real time. Menurut Chun (2006) dalam Romli (2012) penyebutan new media terhadap media online merupakan penyederhanaan istilah terhadap bentuk media di luar lima media massa konvensional (televisi, radio, majalah, koran, dan film). Sifat new media adalah cair, konektivitas individual, dan menjadi sarana untuk membagi peran kontrol dan kebebasan.

McQuail (2011) menjelaskan bahwa "Media Baru atau New Media adalah berbagai perangkat teknologi komunikasi yang berbagi ciri yang sama yang mana selain baru dimungkinkan dengan digitalisasi dan ketersediaannya yang luas untuk penggunaan pribadi sebagai alat komunikasi". Pilihan media untuk mendukung usaha bisnis di era digital seperti sekarang ini sudah semakin beragam, mulai dari media cetak, elektronik, dan kini ada media online. Media online ini yang dianggap sebagai media baru atau new media karena media ini belum ada sebelumnya. Adanya media baru ini karena terjadi pemekaran (konvergensi) media. Media online ini mengandalkan internet untuk dapat mengaksesnya. Media ini muncul seiring dengan kemajuan teknologi informasi dan komunikasi seperti munculnya internet. Informasi dan komunikasi saat ini lebih mudah diakses dengan adanya internet. Para pelaku usaha tentu saja saat ini sangat terbantu sekali dengan adanya media baru ini. Berbagai informasi akan tersampaikan dengan cepat, dan kegiatan usaha dapat dilakukan dalam satu genggaman hanya dengan gawai.

Media online yang biasa digunakan untuk mempromosikan usaha antara lain, media promosi online melalui media sosial contohnya facebook, twitter, dan instagram; media promosi online melalui market place contohnya Lazada, Bukalapak, Tokopedia, dan Shopee; media promosi online melalui website atau blog pribadi; dan media 
promosi online melalui youtube. Terdapat banyak sekali media online yang dapat digunakan untuk mempromosikan sebuah usaha, sehingga siapa saja dapat memulai usahanya di era serba teknologi ini dengan mudah, bahkan untuk pemula sekalipun.

Konsep dasar pemanfaatan media online dikenalkan oleh Delone \& McLean (2001) dalam Assegaff (2017) dengan menggunakan Model Sukses Sistem Informasi (IS Success Model). Model tersebut pernah berhasil diujicobakan pada konteks aplikasi sistem e-commerce. Elemenelemen tersebut yaitu:

1. System Quality/ Kualitas Sistem

Kualitas sistem berkaitan dengan apakah sebuah sistem aplikasi yang dimanfaatkan oleh pengguna terbebas dari bug atau eror ketika diakses. Hal ini juga berkaitan dengan kemudahan penggunaan aplikasi tersebut.

2. Information Quality/ Kualitas Informasi

Kualitas Informasi berkaitan dengan apakah informasi yang disajikan mampu memberikan pengetahuan yang utuh, relevan, mudah dipahami, dan dapat dipercaya.

3. Service Quality/ Kualitas Servi

Kualitas servis berkaitan dengan dukungan dari pengembang sistem aplikasi. Bagian tersebut yang bertanggungjawab terhadap operasional suatu aplikasi jika terjadi hambatan ketika diakses oleh pengguna.

4. System Use/ Penggunaan sistem

Penggunaan sistem ini berkaitan dengan niat atau tindakan pengguna untuk memanfaatkan aplikasi. Hal ini juga berkaitan juga dengan tujuan pengguna menggunakan aplikasi.

5. User Satisfaction/Kepuasaan Pengguna Kepuasaan pengguna ini berkaitan dengan persepsi pengguna setelah mengakses dan memanfaatkan aplikasi tersebut, apakah sistem tersebut sudah sesuai dengan harapan dan kebutuhannya.

6. User Characteristic/Karakteristik Pengguna Pemanfaatan aplikasi dalam hal ini media online sangat dipengaruhi oleh karakteristik penggunanya karena pada aplikasi media online, pengguna tidak terikat pada peraturan tertentu.

\section{METODE PENELITIAN}

Penelitian ini dilakukan pada bulan November 2019 di Sekolah Tinggi Multi Media Yogyakarta, dengan subjek penelitian adalah mahasiswa Sekolah Tinggi Multi Media Yogyakarta. Populasi dalam penelitian ini adalah seluruh mahasiswa di Sekolah Tinggi Multi Media Yogyakarta yang masih aktif sampai bulan Agustus 2019. Jumlah mahasiswa yang menjadi populasi dalam penelitian ini berjumlah 1552 orang. Peneliti mengambil beberapa sampel dari populasi yang akan diteliti tersebut, tetapi sampel yang diambil harus benarbenar representatif karena apa yang akan dipelajari dari sampel itu, kesimpulannya akan diberlakukan untuk semua populasi. Penentuan sampel pada penelitian ini dihitung menggunakan rumus Slovin dan hasil sampel pada penelitian ini berjumlah 94 mahasiswa.

Jenis data yang digunakan adalah data primer yang diperoleh peneliti dari responden secara langsung, dalam hal ini adalah jawaban kuesioner yang diberikan oleh mahasiswa Sekolah Tinggi Multi Media Yogyakarta. Teknik pengumpulan data yang dilakukan dalam penelitian ini dengan menggunakan metode survei melalui pembagian kuesioner kepada responden. Proses penyebaran dan pengumpulan kuesioner dilakukan secara langsung di tempat yang menjadi obyek penelitian.

Uji Kualitas data dilakukan untuk menguji kecukupan dan kelayakan data yang digunakan dalam penelitian. Uji Kualitas data dilakukan menggunakan Uji Validitas dan Uji Reliabilitas. Sebelum melakukan pengujian hipotesis dengan menggunakan persamaan regresi sederhana adalah terpenuhinya asumsi klasik. Uji asumsi klasik yang digunakan adalah dengan Uji Normalitas, Multikolinearitas, Heteroskedastisitas, dan Autokorelasi.

Teknik analisis data dalam penelitian ini menggunakan analisis regresi sederhana yang dioperasikan melalui program SPSS. Analisis ini digunakan untuk mengetahui seberapa besar pengaruh variabel bebas yaitu Pemanfaatan Media Online (X), terhadap variabel terikatnya yaitu Minat Berwirausaha (Y). Sedangkan untuk menguji hipotesis kausalitas menggunakan koefisien determinasi ( $\left.\mathrm{R}^{2}\right)$ dan Uji t (Uji Parsial).

\section{HASIL PENELITIAN DAN PEMBAHASAN}

Uji validitas menggunakan SPSS mensyaratkan nilai Pearson Correlation harus lebih besar dari R Kritis 0,3. Jika nilai Pearson Correlationnya kurang dari 0,3 maka poin instrumen tersebut dianggap gugur dan tidak dipakai (Sugiyono, 2015). Berdasarkan hasil analisis didapatkan nilai Pearson Correlation untuk masing-masing pertanyaan pada variabel minat berwirausaha di atas 0,3, maka sesuai kriteria penerimaan uji validitas berarti poin instrumen untuk variabel yang digunakan dalam penelitian ini valid. Begitu pula dengan variabel pemanfaatan media online untuk masing-masing pertanyaan pada variabelnya didapatkan nilai Pearson Correlation di atas 0,3, maka sesuai kriteria 
https://ejurnal.stimi-bjm.ac.id/index.php/JRIMK

penerimaan uji validitas yang berarti poin instrument untuk variabel yang digunakan dalam penelitian ini valid.

Uji reliabilitas dihitung dengan program SPSS dengan melihat nilai Cronbach's Alpha. Kriteria yang digunakan adalah apabila didapatkan nilai Cronbach's Alpha kurang dari 0,600 berarti buruk, sekitar 0,700 diterima dan lebih dari atau sama dengan 0,800 adalah baik (Sugiyono, 2015). Nilai Cronbach's Alpha pada variabel minat berwirausaha didapatkan nilai sebesar 0,782 berada di sekitar 0,7 sesuai kriteria penerimaan uji reliabilitas yang berarti instrumen dalam penelitian ini dapat diterima dan reliabel. Nilai Cronbach's Alpha pada variabel pemanfaatan media online sebesar 0,810 lebih dari 0,8 sesuai kriteria penerimaan uji reliabilitas yang berarti instrumen dalam penelitian ini adalah baik dan reliabel.

Sampel yang digunakan dalam penelitian ini adalah mahasiswa STMM Yogyakarta berjumlah 90 orang yang terdiri 54 orang laki-laki dan 40 orang perempuan. Berdasarkan hasil kuesioner didapatkan data yaitu waktu yang digunakan mahasiswa untuk mengakses internet lebih dari 7 jam dijawab oleh 48 responden, antara 3 sampai dengan 3 jam dijawab oleh 39 responden, dan antara 1 sampai dengan 3 jam dijawab oleh 7 responden saja. Media yang diakses responden juga beragam, media sosial atau jejaring sosial termasuk messenger, marketplace, dan website atau blog. Rata-rata responden mengakses lebih dari satu media setiap harinya. Dari hasil kuesioner didapatkan bahwa media sosial Instagram paling banyak diakses oleh responden yaitu 87 responden, sedangkan YouTube ada diurutan kedua diakses oleh 74 responden, Twitter ada diurutan ketiga diakses oleh 37 responden, dan facebook ada diurutan keempat diakses oleh 24 responden. Media sosial lain seperti Line, LinkedIn, Pinterest, dan Tumblr tidak banyak diakses, kurang dari 10 responden yang mengakses media tersebut. Selain media sosial, responden juga mengakses marketplace, dan shopee adalah marketplace yang paling banyak diakses oleh responden yaitu 30 responden, tokopedia ada diurutan kedua diakses oleh 13 responden, sedangkan Lazada dan bukalapak diakses kurang dari 10 responden. Sedangkan media seperti website atau blog diakses oleh 44 responden. Profil responden dapat dilihat pada tabel 2 sampai tabel 4 di bawah ini.

Tabel 2

Profil Responden Berdasarkan Jenis Kelamin

\begin{tabular}{ccc}
\hline Waktu akses & Jumlah Responden & Persentase \\
\hline $1-3$ jam & 7 orang & $7,4 \%$ \\
\hline $3-7$ jam & 39 orang & $41,5 \%$ \\
\hline$>7$ jam & 48 orang & $51,1 \%$ \\
\hline
\end{tabular}

Sumber: Data diolah, 2019
Tabel 3

Profil Responden Berdasarkan Waktu Akses Internet

\begin{tabular}{ccc}
\hline Waktu akses & $\begin{array}{c}\text { Jumlah } \\
\text { Responden }\end{array}$ & Persentase \\
\hline $1-3$ jam & 7 orang & $7,4 \%$ \\
$3-7$ jam & 39 orang & $41,5 \%$ \\
$>7$ jam & 48 orang & $51,1 \%$ \\
\hline
\end{tabular}

Sumber: Data diolah, 2019

Tabel 4

Profil Responden Berdasarkan Media yang diakses

\begin{tabular}{ccc}
\hline \multicolumn{2}{c}{ Jenis Media } & $\begin{array}{c}\text { Jumlah } \\
\text { Responden }\end{array}$ \\
\hline Marketplace & Shopee & 30 orang \\
& Lazada & 7 orang \\
& Bukalapak & 4 orang \\
& Tokopedia & 13 orang \\
\hline Media Sosial & YouTube & 74 orang \\
& Instagram & 87 orang \\
& Twitter & 37 orang \\
& Facebook & 24 orang \\
& Line & 9 orang \\
& LinkedIn & 1 orang \\
& Pinterest & 3 orang \\
Website atau & Tumblr & 1 orang \\
Blog & & 44 orang \\
\hline
\end{tabular}

Sumber: Data diolah, 2019

Berdasarkan hasil uji asumsi klasik, uji normalitas pada data penelitian ini ditunjukkan dengan diagram "Normal Probability Plot", dari diagram pada gambar 1 dapat terlihat bahwa titiktitik menyebar di sekitar garis lurus yang berarti grafik menunjukkan pola distribusi normal dan model regresi ini memenuhi asumsi normalitas.

\section{Gambar 1}

\section{Hasil Uji Normalitas}

Hasil uji multikolinearitas ditunjukkan pada tabel 5, dapat dilihat bahwa nilai Tolerance untuk variabel Pemanfaatan Media Online sebesar 1

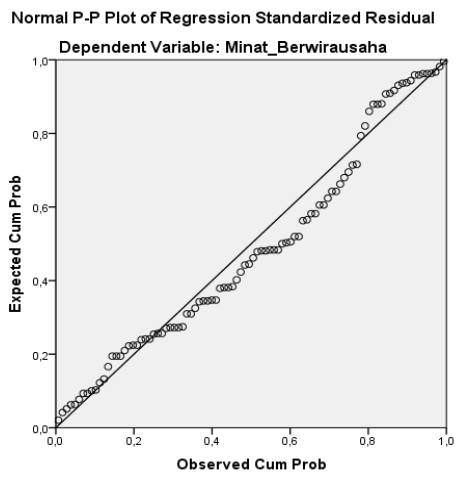


https://ejurnal.stimi-bjm.ac.id/index.php/JRIMK

kurang dari 10 dan nilai VIF sebesar 1 diatas 0,1 yang berarti bahwa model regresi ini terbebas dari multikolinearitas

Tabel 5

Hasil Uji Multikolinearitas

\begin{tabular}{ccc}
\hline Variabel & $\begin{array}{c}\text { Nilai } \\
\text { Tolerance }\end{array}$ & Nilai VIF \\
\hline $\begin{array}{c}\text { Pemanfaatan Media } \\
\text { Online }\end{array}$ & 1,000 & 1,000 \\
\hline
\end{tabular}

Sumber: Data diolah, 2019

Untuk melihat ada atau tidaknya gejala heteroskedastisitas yaitu dengan melihat nilai prediksi variabel terikat (dependen) yaitu antara ZPRED dengan residualnya SRESID pada grafik scatterplot. Jika pada grafik scatterplot tersebut menunjukkan titik-titik yang menyebar dan tidak membentuk pola tertentu seperti bergelombang atau melebar kemudian menyempit, dapat disimpulkan bahwa data tersebut tidak terjadi heteroskedastisitas, tetapi jika me,bentuk pola tertentu maka data tersebut mengindikasikan terjadi heteroskedastisitas.

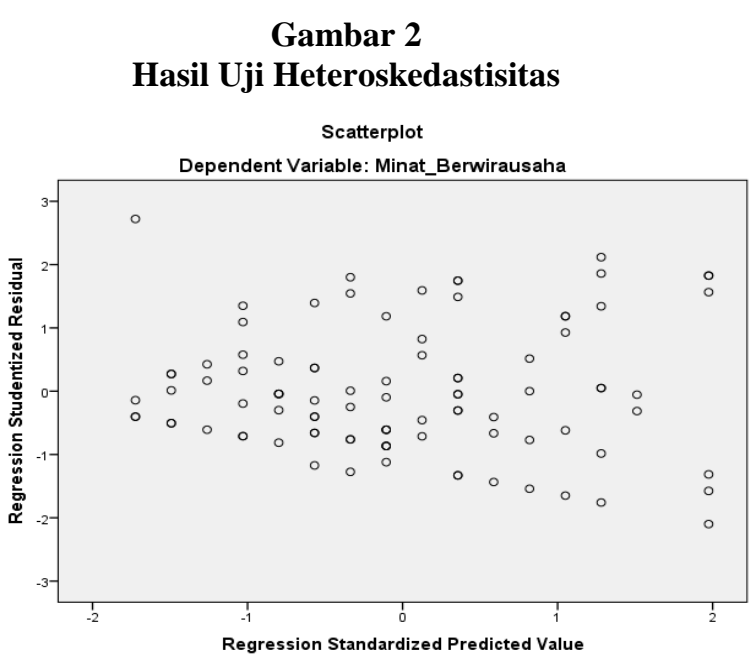

Dari grafik di gambar 2, dapat diketahui bahwa tidak terjadi heteroskedastisitas sebab tidak ada pola yang jelas serta titik-titik menyebar, jadi dapat dikatakan uji heteroskedastisitas terpenuhi.

Hasil Uji Autokorelasi dapat dilihat pada tabel 6 dengan ketentuan jika nilai Durbin-Watson, jika $1,65<\mathrm{D}-\mathrm{W}<2,35$ berarti tidak terjadi autokorelasi dan $\mathrm{D}-\mathrm{W}<1,21$ atau $\mathrm{D}-\mathrm{W}>2,79$ berarti terjadi autokorelasi. Berdasarkan tabel 5 dapat dilihat nilai Durbin Watson diperoleh sebesar 2,233 kurang dari 2,35 yang artinya tidak terjadi autokorelasi dan memenuhi persyaratan uji autokorelasi.
Tabel 6

Hasil Uji Autokorelasi

\begin{tabular}{cccc}
\hline $\mathrm{R}$ & $\mathrm{R}$ Square & $\begin{array}{c}\text { Adjusted } \mathrm{R} \\
\text { Square }\end{array}$ & $\begin{array}{c}\text { Durbin- } \\
\text { Watson }\end{array}$ \\
\hline 0,409 & 0,167 & 0,158 & 1,845 \\
\hline Sumber: Data diolah, 2019 & &
\end{tabular}

Sumber: Data diolah, 2019

Pengujian Hipotesis Kausalitas dalam analisis regresi sederhana ini digunakan untuk mengetahui seberapa besar pengaruh variabel bebas yaitu: Pemanfaatan Media Online (X), terhadap variabel terikatnya yaitu Minat Berwirausaha (Y). Data dalam penelitian ini dianalisis dengan menggunakan analisis regresi sederhana dengan bantuan SPSS. Berdasarkan hasil analisis tersebut didapatkan data seperti yang terlihat dalam tabel 7 di bawah ini.

Tabel 7

Hasil Analisis Regresi Sederhana

\begin{tabular}{cc}
\hline Variabel Independen & Koefisien \\
\hline Pemanfaatan Media Online & 0.405 \\
& Nilai \\
Konstanta & 28.738 \\
R & 0,409 \\
R square & 0,167 \\
F hitung & 18,507 \\
Sig. F & 0,000 \\
\hline Sumber: Data diolah, 2019 &
\end{tabular}

Persamaan regresi linier sederhana untuk penelitian ini adalah sebagai berikut (Ferdinand, 2013):

$\mathrm{Y}=\beta \mathrm{X}+\mu$

Dimana:

$\mathrm{Y}=$ Variabel dependen (Minat

Berwirausaha)

$\beta 1=$ Koefisien regresi

$\mathrm{X} \quad=$ Variabel independen

$\mu \quad=$ error

Dari hasil regresi dapat diperoleh rumus regresi sebagai berikut:

$\mathrm{Y}=0,405 \mathrm{X}+\mu$

Nilai koefisien Pemanfaatan Media Online untuk variabel $\mathrm{X}$ sebesar 0,405 dan bertanda positif hal ini mengandung arti bahwa jika Pemanfaatan Media Online meningkat maka Minat Berwirausaha pada mahasiswa juga akan meningkat, demikian juga sebaliknya jika Pemanfaatan Media Online turun maka Minat Berwirausaha pada mahasiswa juga menurun. Nilai Koefisien Determinasi (R square) adalah nilai yang digunakan untuk mengukur seberapa mampu model persamaan tersebut dalam menjelaskan variasi variabel dependen. Nilai Koefisien determinasi 
adalah antara nol dan satu. Nilai $R$ square yang kecil berarti kemampuan variabel-variabel bebas dalam menjelaskan variasi variabel terikat amat terbatas. Begitu pula sebaliknya, nilai $\mathrm{R}$ square yang mendekati angka satu menjelaskan bahwa variabel-variabel independen menunjukkan hampir semua informasi yang dibutuhkan untuk memprediksi variasi variabel terikat. Nilai $R^{2}$ juga dapat dilihat dari tabel, dari tabel tersebut dapat diketahui bahwa nilai $\mathrm{R}^{2}$ sebesar 0,167 yang berarti Variabel Pemanfaatan Media Online, berpengaruh sebesar $16.7 \%$ sedangkan $83.3 \%$ dapat dijelaskan oleh variabel lain yang tidak ikut diteliti.

Tabel 8

Hasil Uji t Pengaruh Secara Parsial

\begin{tabular}{ccc}
\hline Variabel & Nilai t & $\begin{array}{c}\text { Nilai } \\
\text { Signifikansi }\end{array}$ \\
\hline $\begin{array}{c}\text { Pemanfaatan Media } \\
\text { Online }\end{array}$ & 2,426 & 0,018 \\
\hline
\end{tabular}

Sumber: Data diolah, 2019, Lampiran 4

Uji t digunakan untuk menguji signifikansi hubungan antara variabel $\mathrm{X}$ dan $\mathrm{Y}$, apakah variabel $\mathrm{X}$ benar-benar berpengaruh terhadap variabel $\mathrm{Y}$ secara terpisah atau parsial. Dasar pengambilan keputusan adalah dengan melihat nilai t positif atau negatif dan menggunakan angka probabilitas signifikansi. Misalnya angka probabilitas signifikansi $<0,05$, maka variabel independen berpengaruh secara signifikan terhadap variabel dependen.

Pada tabel 8 dapat dilihat bahwa variabel Pemanfaatan Media Online (X) mempunyai nilai t positif menunjukkan bahwa variabel Pemanfaatan Media Online pada mahasiswa STMM Yogyakarta mempunyai pengaruh yang searah dengan Minat Berwirausaha serta mempunyai nilai signifikansi 0,000 yaitu dibawah 0,05 , jadi dapat disimpulkan variabel Pemanfaatan Media Online memiliki pengaruh positif dan signifikan terhadap Minat Berwirausaha, dengan demikian hipotesis diterima.

Berdasarkan hasil penelitian diperoleh hasil bahwa terdapat pengaruh variabel Pemanfaatan Media Online terhadap Minat Mahasiswa STMM Yogyakarta. Pemanfaatan Media online berpengaruh positif dan signifikan terhadap Minat Berwirausaha. Hasil penelitian ini konsisten dengan penelitian yang dilakukan oleh Alfaruk (2016) dengan judul "Pengaruh Pemanfaatan Sosial Media, Motivasi dan Pengetahuan terhadap Minat Berwirausaha pada Mahasiswa Ekonomi di Universitas Muhammadiyah Sidoarjo" dalam hasil penelitian tersebut dijelaskan bahwa secara parsial variabel pemanfaatan sosial media dan variabel motivasi mempunyai pengaruh yang signifikan terhadap variabel minat berwirausaha pada mahasiswa, sedangkan variabel pengetahuan tidak berpengaruh terhadap variabel minat berwirausaha. Sampel pada penelitian ini adalah mahasiswa Ekonomi Universitas Muhammadiyah Sidoarjo. Penelitian Rahmadi dan Heryanto (2016) tentang "Analisis Faktor-Faktor yang Mempengaruhi Minat Berwirausaha pada Mahasiswa Program Studi Manajemen Fakultas Ekonomi Universitas Kadiri” juga menyimpulkan bahwa lingkungan teknologi merupakan salah satu faktor yang mempengaruhi minat berwirausaha bagi mahasiswa Program Studi Manajemen Fakultas Ekonomi di Universitas Kadiri. Penelitian tersebut juga sejalan dengan penelitian Mulyandi dan Puspitasari (2018) yang menganalisis pengaruh media sosial terhadap minat berwirausaha pada generasi muda sebagai pengembang industri kreatif yang potensial, menyimpulkan bahwa media sosial mempengaruhi minat berwirausaha di kalangan generasi muda.

Terdapatnya pengaruh variabel pemanfaatan media online terhadap minat berwirausaha mengindikasikan bahwa pemanfaatan media secara online mampu mempengaruhi minat mahasiswa di Sekolah Tinggi Multi Media untuk berwirausaha. Dengan demikian diharapkan menjadikan perhatian bagi kampus STMM untuk terus memotivasi mahasiswanya agar dapat menjadi wirausahawan dengan memberikan fasilitas untuk pemanfaatan media online yang terkait dengan kewirausahaan. Mahasiswa yang berwirausaha diharapkan dapat menyerap tenaga kerja dengan usaha yang dijalankannya dan mampu memperpendek masa tunggu untuk mendapatkan pekerjaan ketika sudah lulus, karena wirausahawan justru menciptakan lapangan pekerjaan, serta tidak menjadi bagian dari pengangguran terdidik yang jumlahnya semakin banyak.

Peran pemerintah secara umum dalam memfasilitasi anak-anak muda untuk berwirausaha dapat dilihat dari diluncurkannya Gerakan Nasional 1000 Startup Digital yang diprakarsai oleh Kementerian Komunikasi dan Informatika pada tahun 2016. Gerakan ini merupakan sebuah program pembinaan berkelanjutan selama 6 bulan dari pemerintah untuk masyarakat umum dalam membangun startup digital terutama untuk kalangan muda, karena peserta dibatasi antara usia 18 sampai dengan 40 tahun. Tahun ini dibuka kembali pendaftaran program tersebut hingga akhir tahun. Pada tahun 2018 terdapat lebih dari 32.000 peserta yang telah mendaftarkan diri di Gerakan Nasional 1000 Startup Digital dan telah berlangsung di 10 kota di Indonesia. Jumlah peserta yang telah mengikuti program pembinaan tersebut berjumlah 6500 orang. Total perusahaan rintisan yang sudah melalui proses inkubasi ada sekitar 123 
startup. Program Gerakan Nasional 1000 Startup Digital menyasarkan langsung kepada lima sektor utama yang memiliki peluang inovasi lebih besar seperti Agrikultur, Pendidikan, Kesehatan, Pariwisata dan Logistik, (https://www.indotelko.com/read/1520138930/ perkembangan-gerakan-1000-startup, diakses tanggal 25 November 2019).

Dalam hal ini kampus juga diharapkan dapat memfasilitasi mahasiswa dalam berwirausaha misalnya mengadakan laboratorium kewirausahaan yang berbasis teknologi yang dapat digunakan sebagai proyek awal untuk menciptakan lapangan usaha secara berkelompok dan mendapatkan pembinaan dari kampus secara berkelanjutan. Menciptakan forum-forum diskusi kewirausahaan khususnya di bidang yang dinaungi oleh Kementerian Komunikasi dan Informatika sebagai induk dari STMM Yogyakarta. Pada dasarnya mahasiswa yang telah lulus kemudian bekerja atau mencari lowongan pekerjaan adalah tanggung jawab masing-masing mahasiswa dan bukan tanggung jawab kampus untuk menyalurkannya karena STMM Yogyakarta bukan kampus dengan ikatan dinas. Akan tetapi jumlah mahasiswa yang telah bekerja dengan masa tunggu tertentu akan berkontribusi kepada kampus dalam hal penilaian akreditasi lembaga tersebut. Sehingga kampus mempunyai kewajiban menjadikan mahasiswa sesuai output yang dijanjikan masing-masing program studi. Berwirausaha menjadi salah satu alternatif pekerjaan yang tidak mengharuskan mahasiswa lulus terlebih dahulu. Pemanfaatan media secara online dari hasil penelitian ini terbukti mempengaruhi minat berwirausaha bagi mahasiswa STMM Yogyakarta.

\section{PENUTUP}

\section{Simpulan}

Berdasarkan hasil penelitian dan pembahasan pada bab sebelumnya, maka dapat disimpulkan bahwa terdapat pengaruh positif atas pemanfaatan media online terhadap minat berwirausaha bagi mahasiswa Sekolah Tinggi Multi Media Yogyakarta. Jadi dapat dijelaskan bahwa semakin tinggi pemanfaatan media online di kalangan mahasiswa STMM, maka semakin tinggi pula minat mahasiswa STMM Yogyakarta untuk berwirausaha, demikian pula sebaliknya jika semakin rendah pemanfaatan media online di kalangan mahasiswa STMM Yogyakarta, maka semakin rendah pula minat berwirausaha pada mahasiswa STMM Yogyakarta.
Penelitian ini dapat dijadikan acuan bagi STMM Yogyakarta, bahwa pemanfaatan media online dapat mempengaruhi minat mahasiswa dalam berwirausaha. Oleh karena itu kampus harus memperhatikan faktor ini agar mahasiswa STMM Yogyakarta dapat berwirausaha sejak dini atau saat lulus nanti. Penelitian berikutnya agar menambah sampel mahasiswa STMM atau mahasiswa di luar STMM agar terlihat dinamika minat berwirausaha di kalangan mahasiswa. Penelitian berikutnya agar menambahkan metode pengumpulan data seperti wawancara kepada responden agar tambahan data kualitatif yang didapat menjadikan hasil penelitian lebih akurat.

\section{DAFTAR PUSTAKA}

Alfaruk, M., H. (2016). Pengaruh Pemanfaatan Sosial Media, Motivasi dan Pengetahuan terhadap Minat Berwirausaha pada Mahasiswa Ekonomi di Universitas Muhammadiyah Sidoarjo. Jurnal Ekonomi Pendidikan dan Kewirausahaan, 4(2), 164172.

Assegaff, Setiawan. (2017). Evaluasi Pemanfaatan Media Sosial sebagai sarana Knowledge Sharing. Jurnal Manajemen Teknologi, 16(3), 271-293.

Djamarah, S., Bahri. (2011). Psikologi Belajar, Cetakan ke 3, Edisi Revisi. Jakarta: PT. Rineka Cipta.

Ferdinand, Augusty (2013). Metode Penelitian Manajemen: Pedoman Penelitian Untuk Penulisan Skripsi, Tesis, dan Disertasi Ilmu Manajemen, Edisi 4. Semarang: Badan Penerbit Universitas Diponegoro.

Husamah, Pantiwati, Y., Restian, A., \& Sumarsono, P. (2016). Belajar dan Pembelajaran. Malang: UMM Press.

Mulyandi, M., R., \& Puspitasari, V., A. (2018). Industri Kreatif, Media Sosial, Dan Minat Berwirausaha: Sinergi Menuju Pembangunan Berkelanjutan. National Conference of Creative Industri: Sustainable Tourism Industri for Economic Development Universitas Bunda Mulia, Jakarta, 5-6 September 2018 eISSN No: 2622-7436.

McQuail, Denis. (2011). Teori Komunikasi Massa. Jakarta: Salemba Humanika.

\section{Saran}


Jurnal Riset Inspirasi Manajemen dan Kewirausahaan Volume 4 No. 2 Edisi September 2020 ISSN: 2549-3477 e-ISSN: 2623-1077 DOI : https://doi.org/10.35130/jrimk

https://ejurnal.stimi-bjm.ac.id/index.php/JRIMK

Rachmadi, A., \& Heryanto, B. (2016). Analisis Faktor-Faktor yang Mempengaruhi Minat Berwirausaha pada Mahasiswa Program Studi Manajemen Fakultas Ekonomi Universitas Kadiri. Jurnal EkoNika, 1(2), 153-169.

Romli, A., Syamsul. (2012). Jurnalistik Online Panduan Praktis Mengelola Media Online. Bandung: Nuansa Cendikia.

Rusdiana, Dr., H., A., M.M. (2018).

Kewirausahaan Teori Dan Praktik.

Bandung: CV. Pustaka Setia.

Sugiyono. (2015). Metode Penelitian Kuantitatif, Kualitatif, dan $R \& D$. Bandung: Alfabeta.
Sunyoto, Danang. (2016). Metodologi Penelitian Akuntansi. Bandung: PT Refika Aditama.

Suryana. (2013). Kewirausahaan Kiat dan Proses Menuju Sukses. Jakarta: Salemba Empat.

Takdir, D., Mahmudin AS., \& Zaid, S. (2015). Kewirausahaan. Yogyakarta: Wijaya Mahadi Karya.

www.indotelko.com (4 Maret 2018). Perkembangan Gerakan 1000 Startup. Dipetik 25 November 2019 dari: https://www.indotelko.com/read/1520138 930/perkembangan-gerakan-1000-startup

Profil Penulis:

1. Dhety Chusumastuti, SE, MM

Sekolah Tinggi Multi Media "MMTC" Yogyakarta, Jl. Magelang Km.6 Yogyakarta 55284

Email: dhet001@kominfo.go.id 